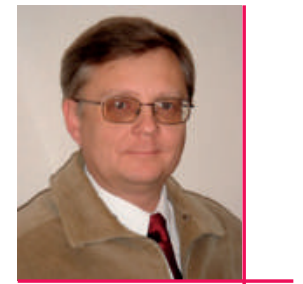

Шумаков И.В.

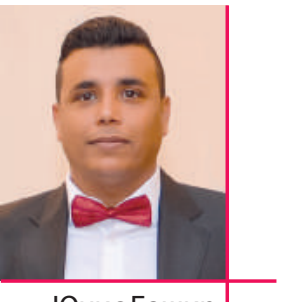

Юнис Башир

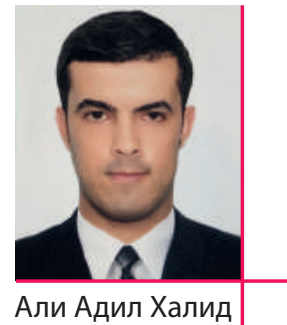

Шумаков И.В., д.т.н., професор,

зав. кафедрой технологии строительного производства,

๘+38 (097) 941-33-28凶 shumakov.hisi@gmail.com,

Юнис Башир, к.т.н.

доцент кафедры строительной механики,

๘+38 (093) 661-04-94凶 docbasheer01@gmail.com,

Али Адил Халид, аспирант,

Харьковский национальный университет

строительства и архитектуры (ХНУСА),

ул. Сумская, 40, г. Харьков, 61002
Igor Shumakov, D.Sc,

Head the Department of construction technologies, ๘+38 (097) 941-33-28凶 shumakov.hisi@gmail.com, Basheer N. Younis, Ph. D.

assistant professor of structural mechanics Department

¿ +38 (093) 661-04-94凶 docbasheer01@gmail.com,

Adil Khalid Ali, postgraduate student,

Kharkiv National University

of Civil engineerng and Architecture,

Str. Sumy, 40, Kharkov, 61002

\title{
ТРУБЧАТЫЕ БЕТОННЫЕ БУРО-ВИБРОВАКУУМИРОВАННЫЕ СВАИ ДЛЯ МАЛОЭТАЖНОГО СТРОИТЕЛЬСТВА
}

\section{ТРУБЧАСТІ БЕТОННІ БУРО-ВІБРОВАКУУМІРОВАНІ ПАЛІ ДЛЯ МАЛОПОВЕРХОВОГО БУДІВНИЦТВА CONCRETE PILES WITH HOLLOW SECTION CASTED BY VIBRATION - EVACUATION FOR LOW-RISE CONSTRUCTION}

Аннотация. В статье рассматриваются способы формования трубчатых свай. Проведён анализ существующих способов формования свай, выявлены недостатки и предложены пути решения основных проблем с помощью усовершенствованного способа вибровакуумирования. Ключевые слова: сваи, вибровакуумирование, бетон, пустотелая секция, прочность при сжатии.

Анотація. У статті розглядаються засоби формовання трубчастих паль. Проведено аналіз існуючих способів формування паль, виявлено недоліки та запропоновано шляхи вирішення основних проблем за допомогою вдосконаленого способу вібровакуумірованія. Ключові слова:палі, вібровакуумування, бетон, пустотіла секція, міцність при стисканні.

Summary. The article considers ways to mold for pipe piles. Analysis of existing methods of forming piles, identified gaps and proposed solutions to the major problems with the improved method of vibro- vacuum.

Keywords: pile, vibration, concrete, hollow section, compressive strength.

\section{Актуальность проблемы}

В настоящее время в Ираке ощущается значительный дефицит жилья, обветшал жилищный фонд, эта проблема остро стоит для молодых семей и военнослужащих. Не менее актуально строительство жилья в сельской местности и для развивающихся представителей фермерского движения. Кроме того, для жителей Ирака является очевидным желание повышать уровень жизни и существенная часть населения стремится увеличить размеры жилья и обеспечить комфортные условия проживания в нем.

Учитывая, что платежеспособность основной массы населения городов и сел на сегодняшний день остается низкой, необходимо применять такие способы строительства, которые бы способствовали вовлечению в процесс самих нуждающихся в жилье граждан.

На наш взгляд, пришло время для создания технологий строительства, позволяющих, по возможности, своими руками способствовать решению жилищной проблемы, отдавая предпочтение индивидуальному строительству с ориентировкой на создание дешевого, доступного для большинства работающих граждан жилья с учетом достижений строительной науки, строительного материаловедения и опыта возведения жилья.

Одним из наиболее важных аспектов рассматриваемой проблемы является повышение надежности и долговечности возводимых объектов. При этом необходимо учитывать влияние условий строительства и эксплуатации по параметрам прочности, теплоэффективности несущих и ограждающих конструкций и облицовочных элементов здания.

К перспективным конструктивным решениям малоэтажного жилищного строительства относится фундамент в виде трубчатых бетонных буро-вибровакуумированных свай. Кроме того, эффективным является проектирование стеновых конструкций с утеплителем. Замена в несущих конструкциях метал- лической арматуры на композитную исключает риск ее коррозии, являющейся основной причиной разрушения железобетонных изделий и снижающей сроки безаварийной эксплуатации зданий, в том числе и малоэтажных.

Технологическая последовательность выполнения работ включает в себя:

- $\quad$ устройство трубчатых фундаментов непосредственно на строительной площадке в скважинах, пробуренных в грунте;

- устройство ростверка;

- $\quad$ возведение наружных стен из полых элементов с заполнением полостей эффективным теплоизоляционным материалом;

- устройство сплошных колонн на пересечениях наружных стен;

- $\quad$ устройство обвязки под перекрытие из сплошных балок. Для укладки и уплотнения бетонной смеси в современном строительстве применяют вибрирование, виброштампование, вибропрокат, вибровакуумирование, центрифугирование, а также комбинированные способы, когда сочетаются известные способы формования, к примеру, вибрирование бетонной смеси и прессование, центрифугирование, прокат и т.п.

\section{Цель}

Разработка способа формования трубчатых фундаментов методом вибровакуумирования непосредственно на строительной площадке в скважинах, пробуренных в грунте при строительстве малоэтажных зданий.

Анализ публикаций по теме исследования

В статье использовались и анализировались работы в области строительных материалов и способов формования 
изделий Ю.М. Баженова, А.Г. Комара [1], Б.Г. Скрамтаева, А.Е. Десова [2]. Анализ данных работ позволяет рассмотреть способы формования свай, в них изучался способ вибровакуумирования. Вибровакуумирование является комплексным способом формования изделий, включающим снижение исходного водосодержания бетонной смеси путем ее вакуумирования и повторно-кратковременного вибрирования. Формование изделий производится на установках вертикального и горизонтального типа, обеспечивающих уплотнение бетонной смеси, немедленную распалубку и беспетлевой съем свежеотформованных изделий. Выбор рационального способа формования определяется конструктивными особенностями формуемых строительных изделий, технологической схемой производства, степенью и видом армирования изделий, их массой и габаритами, требованиями к качеству уплотнения бетонной смеси и качеству поверхности изделия, номенклатурой и объемом производства изготовляемых изделий для малоэтажного строительства [1]. Запатентованные решения [3, 4] безусловно продвинули очерченную проблему к эффективному решению, однако они характеризуются сложностью и трудностями при контроле качества.

Авторы, работавшие в данном направлении, обосновывают эффективность вибровакуумирования, которое обеспечивает интенсивный рост прочности бетона в начальный период твердения, сокращение времени на тепловую обработку изделий или отказ от нее, уменьшение металлоемкости технологического оборудования. Степень уплотнения бетонной смеси зависит от частоты и амплитуды колебаний вибратора, а также от продолжительности вибрирования. Для уплотнения бетонных смесей амплитуда колебаний находится в пределах 0,3 $\div 0,7$ мм при частоте колебаний около 3000 в мин. [5, 6, 7].

При этом полученных результатов недостаточно для комплексного подхода к повышению производительности работ и качества формуемых свай.

\section{Изложение основного материала}

Известен способ формования трубчатых свай, включающий цилиндрическую головку, закрепленную на приводном валу с возможностью вращения и вертикального перемещения, и расположенную на головке уплотняющую спиралевидную лопасть. Цилиндрическая головка, вращаясь, равномерно распределяет бетонную смесь по окружности формы, тем самым исключая возможность образования разрывов в стенках трубы. Спиралевидная лопасть, опираясь на укладываемый бетон, послойно его уплотняет, при этом обеспечивает самоподъем головки по мере бетонирования трубы.

Однако такой способ не гарантирует высокого качества формуемых изделий. В одной и той же свае могут быть участки высокого качества уплотнения наряду с недостаточно уплотненными. Причиной этого может быть недостатки контроля качества и невозможность поддержания постоянного слоя рыхлой бетонной смеси над спиральной лопастью.

При устройстве свай по мере извлечения устройства из скважины, бетонная смесь уплотняется с помощью вибратора и раздвигается конусной головкой в стороны стенок скважины.

Однако недостатком известного устройства является низкое качество формования свай. Для решения существующей задачи предложено формование бетонных и армированных свай широко применяемым встроительстве способом вибровакуумирования (рис. 1). Поставленная цель достигается за счет того, что используются подвижные или литые бетонные смеси с укладкой в межстенное пространство между грунтом и металличе- ским устройством с одновременным вибрированием и вакуумированием.

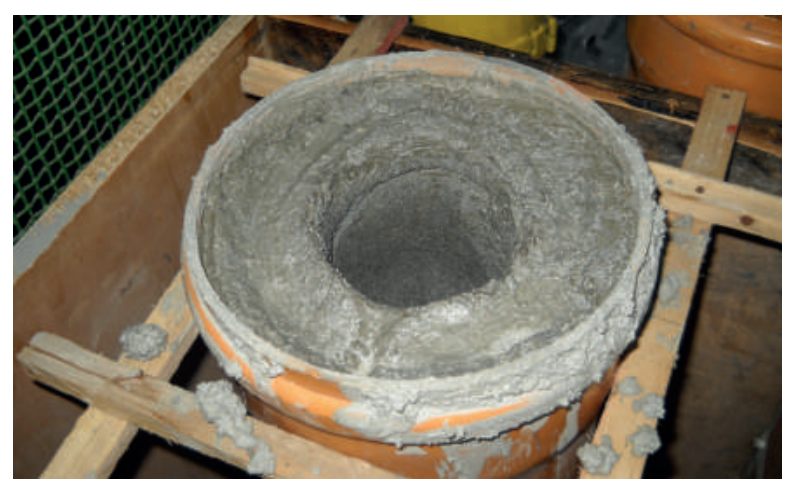

Рис. 1. Общий вид сформованной сваи

Экспериментально установлено, что высокое качество свай достигается при использовании способа формования свай вибровакуумированием. В результате такой обработки бетонная смесь уплотняется, что в свою очередь повышает физико-механические свойства.

Результаты проведенных исследований приведены в табл. 1.

Таблиця 1

Міцність фібробетонних зразків з різним вмістом та співвідношенням сталевої та базальтової фібри

\begin{tabular}{|c|c|c|c|c|}
\hline № & $\begin{array}{c}\text { Наименование } \\
\text { сваи }\end{array}$ & $\begin{array}{c}\text { Плотность } \\
\text { изготов- } \\
\text { ленной } \\
\text { сваи, кг/м³ }\end{array}$ & $\begin{array}{c}\text { Прочность } \\
\text { при сжа- } \\
\text { тии, } \\
\text { МПа }\end{array}$ & $\begin{array}{c}\text { Прочность } \\
\text { при растя- } \\
\text { жении, } \\
\text { МПа }\end{array}$ \\
\hline 1 & $\begin{array}{c}\text { Свая, выполненная } \\
\text { методом литья }\end{array}$ & 2236 & 20,7 & 4,43 \\
\hline 2 & $\begin{array}{c}\text { Свая, выполненная } \\
\text { методом виброва- } \\
\text { куумирования }\end{array}$ & 2410 & 28,3 & 6,37 \\
\hline
\end{tabular}

Из табл. 1 видно, что плотность бетона повышается на более чем $10 \%$, прочность на сжатие на $36 \%$, а прочность при растяжении на $43 \%$.

\section{Вывод}

В результате проведенных исследований были выявлены основные проблемы качества при устройстве бетонных и железобетонных свай существующими способами формования. Предложенный способ формования вибровакуумированием улучшает прочностные характеристики свайных конструкций.

Литература:

1. Баженов Ю.М., Комар А.Г. Технология бетонных и железобетонных изделий. Москва : Стройиздат, 1984. 673 C.

2. Скрамтаев Б.Г., Десов А.Е. Вакуумирование бетона. Строительная промышленность. 1938. №3. С.64-72.

3. Патент на винахід. Пристрій для формування трубчатих конструкцій з бетонних сумішей. UA $2637 \mathrm{Cl}$ 26.12.94. Бюл. №5-1.

4. Авторское свидетельство СССР № 1079757, Е 02 D $5 / 38,1984$.

5. Сторожук Н.А. Свойства вакуум-бетона. Строительные материалы и конструкции. 1990. № 1. С.27-28.

6. Асирьян А.М. Исследование новых возможностей использования вакуума в технологии бетонов : дис. канд. техн. наук : 05.23.05. Ереван, 1966. 133 с.

7. Гершберг О.А., Итин А.Е. Вакуумбетон. Строительная промышленность. 1941. № 7-8. С.16-19. 